\title{
Phylogenetic diversity of Flavobacteria isolated from the North Sea on solid media
}

\author{
Richard L. Hahnke, Jens Harder* \\ Department of Microbiology, Max Planck Institute for Marine Microbiology, Celsiusstr. 1, D-28359 Bremen, Germany
}

\section{A R T I C L E I N F O}

\section{Article history:}

Received 20 December 2012

Received in revised form 27 May 2013

Accepted 5 June 2013

\section{Keywords:}

Helgoland

Flavobacteria

Flexirubin

Cultivation

North Sea

Iridescence

Taxonomy

Bacteroidetes

Janssand

Sylt

\begin{abstract}
A B S T R A C T
Flavobacteria are abundant in the North Sea, an epeiric sea on the continental shelf of Europe. However, this abundance has so far not been reflected by the number of strains in culture collections. In this study, Flavobacteria were isolated from pelagic and benthic samples, such as seawater, phytoplankton, sediment and its porewater, and from surfaces of animals and seaweeds on agar plates with a variety of carbon sources. Dilution cultivation with a new medium, incubation at low temperatures and with long incubation times, and colony screening by a Flavobacteria-Cytophagia-specific PCR detecting 16S rRNA gene sequences led to a collection of phylogenetically diverse strains. Two strains affiliated with Flammeovirgaceae and seven strains affiliated with Cyclobacteriaceae, whereas within the Flavobacteriaceae 20 isolated strains presumably represented seven novel candidate genera and 355 strains affiliated with 26 of 80 validly described marine Flavobacteriaceae genera, based on a genus boundary of $95.0 \% 16 \mathrm{~S}$ rRNA gene sequence identity. The majority of strains (276) affiliated with 37 known species in 16 genera (based on a boundary of $98.7 \% 16 \mathrm{~S}$ rRNA gene sequence identity), whereas 79 strains likely represented 42 novel species in 22 established Flavobacteriaceae genera. Pigmentation, iridescence, gliding motility, agar lysis, and flexirubin as a chemical marker supported the taxonomy at the species level. This study demonstrated the culturability on solid medium of phylogenetically diverse Flavobacteria originating from the North Sea.
\end{abstract}

(c) 2013 Elsevier GmbH. All rights reserved.

\section{Introduction}

Flavobacteria are common in epipelagic oceanic and coastal waters as well as in benthic habitats, accounting for $10-30 \%$, and sometimes up to $70 \%$, of the bacterial populations [14,20,55]. Together with Alphaproteobacteria, Flavobacteria have been shown to be more abundant in the particle-associated fraction, whereas Gammaproteobacteria were dominantly free floating [1]. Flavobacteria are known to attach to phytoplankton [20] and to participate in the initial degradation of complex organic matter, thus playing an important part in the carbon cycle [28]. In a decaying phytoplankton spring bloom in the North Sea, Flavobacteria populations dominated the initial degradation process [49]. The German Bight in the North Sea is a shallow coastal area with high tidal dynamics [38] whose seafloor is a major sink of organic matter and nitrogen species [2,19]. In this coastal region, Flavobacteria were a dominating population in the microbial community in surface seawater, accounting for up to $55 \%$ of bacterioplankton cells [14]. In the benthos, Flavobacteria were the most abundant phylogenetic group, accounting for $15-25 \%$ of all cells [31]. In

\footnotetext{
* Corresponding author. Tel.: +49 4212028750.

E-mail address: jharder@mpi-bremen.de (J. Harder).
}

2006, the Flavobacteriaceae comprised 168 species in 53 genera [6]. However, this family has increased to 393 species in 95 genera (www.bacterio.cict.fr, June 2012) [15], and marine strains represented 210 Flavobacteriaceae-type strains in 80 genera (Table S1).

In contrast to the population size, previous attempts to cultivate representatives of bacterial communities from the Wadden Sea obtained a low number of Flavobacteriaceae strains, irrespective of whether they originated from seawater [14] or intertidal sediment [47]. In both cases, polymeric carbohydrates (e.g. chitin, cellulose and agar) did not support an increase in culturability. The authors concluded that (I) frequently isolated bacteria were of low abundance in nature [14], and (II) Flavobacteria did not grow well on solid agar [47]. Nevertheless, seven novel species of Flavobacteriaceae have been isolated and described from the North Sea in recent years. Leeuwenhoekiella marinoflava [35] was cultivated from the seawater of the coast of Aberdeen [12], whereas Maribacter forsetii [4] and 'Gramella forsetii' [5] were isolated from the seawater of Helgoland, an island in the German Bight. Muricauda ruestringensis was isolated from the intertidal sediment near the former village of Rüstringen [9]. Tenacibaculum ovolyticum was isolated from the epiflora of halibut eggs from Bergen, Norway [22,48]. Tenacibaculum skagerrakense was isolated from the seawater of Skagerrak, Denmark [18], and Cellulophaga fucicola from the brown alga Fucus of Hirsholm Island, Denmark [24]. 
Therefore, the aim of the current study was to collect phylogenetically diverse Flavobacteriaceae from different locations and sample types of the German Bight in the North Sea. Improved techniques were explored for isolating marine Flavobacteria using suitable medium components, and PCR with a FlavobacteriaCytophagia-specific primer for the 16S rRNA gene enabled fast identification of Flavobacteria colonies.

\section{Materials and methods}

\section{Sampling}

Samples were collected with Niskin bottles, $20 \mu \mathrm{m}$ - or $80 \mu \mathrm{m}$ plankton nets, sterile syringes or tubes at Helgoland, Harlesiel, Janssand and the Königshafen, Hausstrand/List and Weststrand sites on Sylt (Table S1). Samples were stored at in situ temperature, transported to the laboratory within one to three hours and directly processed.

\section{Medium preparation}

Artificial seawater (ASW) and all media were prepared with sterile filtered $(0.2 \mu \mathrm{m}$ polycarbonate filter) ultra pure water (Aquintus system, membraPure, Germany) with a resistivity of $18.3 \mathrm{M} \Omega \mathrm{m}$. For dilutions and washing steps, ASW was prepared following the recipe of Widdel and Bak [52], as described by Winkelmann and Harder [53]. Basal salts: $26.37 \mathrm{~g} \mathrm{NaCl}$, $5.67 \mathrm{~g} \mathrm{MgCl}_{2} \times 6 \mathrm{H}_{2} \mathrm{O}, 6.8 \mathrm{~g} \mathrm{MgSO}_{4} \times 7 \mathrm{H}_{2} \mathrm{O}, 0.19 \mathrm{~g} \mathrm{NaHCO}, 1.47 \mathrm{~g}$ $\mathrm{CaCl}_{2} \times 2 \mathrm{H}_{2} \mathrm{O}, 0.72 \mathrm{~g} \mathrm{KCl}, 0.10 \mathrm{~g} \mathrm{KBr}, 0.02 \mathrm{~g} \mathrm{H}_{3} \mathrm{BO}_{3}, 0.02 \mathrm{~g} \mathrm{SrCl}_{2}$ and $0.003 \mathrm{~g} \mathrm{NaF}$ were dissolved in $1 \mathrm{~L}$ water. After autoclaving at $121^{\circ} \mathrm{C}$ for $25 \mathrm{~min}$ and cooling, the ASW was slowly adjusted to $\mathrm{pH}$ 7.5 with autoclaved $1 \mathrm{M} \mathrm{NaOH}$ or $1 \mathrm{M} \mathrm{HCl}$. Autoclaved water was used to replace the evaporated water. The ASW had a salinity of $34 \%$ S, which was comparable to the euhaline (>30\% S) sampling sites.

ZoBell [56,57] suggested the marine medium 2216 with yeast extract $(=2216 \mathrm{E}$ ) for the cultivation of most marine bacteria, which is nowadays sold as marine agar 2216, and it was prepared following the manufacturer's instructions (Difco Laboratories, Detroit, USA). The evaporated water was replaced by autoclaved water. Other solid media with defined carbon sources required the preparation of twofold concentrated ASW and purification of Bacto Agar (Difco Laboratories, Detroit, USA). Agar $\left(18 \mathrm{~g} \mathrm{~L}^{-1}\right)$ was washed three times with $700 \mathrm{~mL}$ ultra pure water, in order to remove soluble substances that may inhibit bacterial growth [23,52]. Solid HEPES $(50 \mathrm{mM})$ and $500 \mathrm{~mL}$ twofold ASW were added to the agar suspension. After autoclaving, the medium was cooled to $55^{\circ} \mathrm{C}$ and supplemented with $5 \mathrm{~mL} \mathrm{NH}_{4} \mathrm{Cl}\left(50 \mathrm{~g} \mathrm{~L}^{-1}\right.$, autoclaved), $10 \mathrm{~mL} \mathrm{KH}_{2} \mathrm{PO}_{4}\left(50 \mathrm{gL}^{-1}\right.$, autoclaved), $2 \mathrm{~mL}$ trace element solution (per L: $\mathrm{FeSO}_{4} \times 7 \mathrm{H}_{2} \mathrm{O}, 2.1 \mathrm{~g}$; $\mathrm{Na}_{2}$-EDTA, $5.2 \mathrm{~g}$; $\mathrm{H}_{3} \mathrm{BO}_{3}, 30 \mathrm{mg} ; \mathrm{MnCl}_{2} \times 4 \mathrm{H}_{2} \mathrm{O}, 100 \mathrm{mg} ; \mathrm{CoCl}_{2} \times 6 \mathrm{H}_{2} \mathrm{O}, 190 \mathrm{mg} ;$ $\mathrm{NiCl}_{2} \times 6 \mathrm{H}_{2} \mathrm{O}, 24 \mathrm{mg} ; \mathrm{CuCl}_{2} \times 2 \mathrm{H}_{2} \mathrm{O}, 10 \mathrm{mg} ; \mathrm{ZnSO}_{4} \times 7 \mathrm{H}_{2} \mathrm{O}, 144 \mathrm{mg} ;$ $\mathrm{Na}_{2} \mathrm{MoO}_{4} \times 2 \mathrm{H}_{2} \mathrm{O}, 36 \mathrm{mg}$; $\mathrm{pH}$ adjusted to 6.0 with $5 \mathrm{M} \mathrm{NaOH}$ [37]), and $0.7 \mathrm{~mL} \mathrm{SeW}$ solution [52]. Carbon sources for the SYL media were $2 \mathrm{~g} \mathrm{~L}^{-1}$ of yeast extract, peptone tryptone, casamino acids, glucose, cellobiose, $\mathrm{N}$-acetylglucosamine, xylose, galactose, malate, arabinose or rhamnose, for the HAR medium $0.3 \mathrm{~g} \mathrm{~L}^{-1}$ of casamino acids and $0.5 \mathrm{~g} \mathrm{~L}^{-1}$ of glucose, xylose and $\mathrm{N}$-acetylglucosamine, and for the HaHa medium $0.5 \mathrm{~g} \mathrm{~L}^{-1}$ of yeast extract, peptone tryptone, casamino acids, glucose, and cellobiose. The SYL media received, per litre, $1 \mathrm{~mL}$ 7-vitamin solution [53], $1 \mathrm{~mL}$ vitamin $\mathrm{B}_{12}$ solution [52], $1 \mathrm{~mL}$ thiamine solution [53], and $1 \mathrm{~mL}$ riboflavin solution [53]. The $\mathrm{pH}$ was slowly adjusted to 7.5 with autoclaved $1 \mathrm{M} \mathrm{NaOH}$. Evaporated water was replaced with autoclaved water before the plates were poured.

\section{Isolation and cultivation}

To enrich sediment-attached bacteria, $5 \mathrm{~mL}$ of the sediment from Harlesiel were sampled with a sterile cut-off syringe. The sediment was washed successively five times with $40 \mathrm{~mL}$ sterile artificial sea water in a $50 \mathrm{~mL}$ polypropylene tube, which resulted in approximately $5.5 \times 10^{4}$ cells $\mathrm{mL}^{-1}$ sediment. Sediments were allowed to settle for $30 \mathrm{~min}$ and supernatants were decanted. The washed sediment was incubated in HAR liquid medium at $25^{\circ} \mathrm{C}$ for $24 \mathrm{~h}$. The sediment was mixed with the medium in an overhead rotator at $25 \mathrm{rpm}$ (Reax 2, Heidolph, Schwabach, Germany). The next day, the sediment was washed five times with artificial seawater $(40 \mathrm{~mL})$ and afterwards incubated for $48 \mathrm{~h}$ and $96 \mathrm{~h}$ in HAR liquid medium. The supernatants were decanted and collected in fresh, sterile $50 \mathrm{~mL}$ polypropylene tubes. Samples of the sediment or the supernatant were incubated on solid HAR medium.

Kanamycin was reported to select for Flavobacteria [17]. Therefore, surface intertidal sediments from Königshafen of Sylt, Janssand or Harlesiel were incubated on SYL agar, optionally supplemented with $50 \mu \mathrm{g} \mathrm{mL}^{-1}$ kanamycin [17] and incubated at $25^{\circ} \mathrm{C}$ for 3-4 weeks.

For inoculation, seawater aliquots were spread on solid agar plates using sterile glass beads, and sediment was spread on agar plates with an inoculating loop. Algae were chopped and washed with sterile artificial seawater. Animal specimens were washed with seawater and sterile artificial seawater. A 96-pin replicator enabled the transfer of $1 \mu \mathrm{L}$ per pin onto 96 defined positions on the agar surface in a $150 \mathrm{~mm}$ Petri dish [53]. HAR and HaHa agar plates were incubated at $11^{\circ} \mathrm{C}$ and SYL agar plates at room temperature $\left(22^{\circ} \mathrm{C}\right)$ for at least two months. Single colonies were examined and transferred three times to new plates in order to obtain pure strains. Colonies were characterized by phenotypic characteristics as well as Flavobacteria-Cytophagia-specific 16S rRNA gene amplification and sequence analysis. Strains were maintained as viable cultures on 2216 marine agar or on HaHa agar plates at $4^{\circ} \mathrm{C}$ and also cryopreserved at $-80^{\circ} \mathrm{C}$ in artificial seawater supplemented with $30 \%$ (v/v) glycerol.

\section{Phenotypic characterization}

The bathochromic shift test with $20 \%$ (w/v) $\mathrm{KOH}$ was performed to detect flexirubin-type pigments [16] (Fig. S6). Cell shapes were visualized with phase contrast microscopy. Shape and colour of colonies on the agar plate were visualized with a binocular microscope.

\section{S rRNA gene analysis}

Two protocols were applied to release DNA from cells. A tiny amount of a colony was dissolved from a sterile wooden toothpick in $20 \mu \mathrm{L}$ PCR water. After three freeze/thaw cycles $\left(-20^{\circ} \mathrm{C} /+4^{\circ} \mathrm{C}\right)$, one microlitre served as PCR template. Alternatively, the smallest separable part of the colony was squashed in $100 \mu \mathrm{L} \mathrm{PCR}$ water and lysed by three freeze/thaw cycles. The frozen sample finally received $100 \mu \mathrm{L}$ PCR water and was thawed without mixing. Ten $\mu \mathrm{L}$ of supernatant served as PCR template. The $16 \mathrm{~S}$ rRNA gene was amplified with the general bacterial primers GM3F (5' AGA GTT TGA TYM TGG CTC AG-3') (positions 8-27 according to Escherichia coli numbering) and 907R (5'-CCG TCA ATT CCT TTR AGT TT-3') [34], as well as with the primers GM3F and CF1489R. The Flavobacteria-Cytophagia-specific reverse primer CF1489R (5'-TAC CTT GTT ACG ACT TAG C-3', positions 1489-1507) was designed and validated with the ARB software [32] on the dataset SILVA ref108_NR99 [39] and with SILVA TestPrime [29]. PCR amplifications were performed in $25 \mu \mathrm{L}$ with $96^{\circ} \mathrm{C}$ for $4 \mathrm{~min}, 35$ cycles of $96{ }^{\circ} \mathrm{C}$ for $1 \mathrm{~min}, 55$ or $62^{\circ} \mathrm{C}$ for $1 \mathrm{~min}$ - for primer pair GM3F, 907R 
and GM3F, CF1489R, respectively $-72{ }^{\circ} \mathrm{C}$ for $3 \mathrm{~min}$ and a final elongation at $72{ }^{\circ} \mathrm{C}$ for $10 \mathrm{~min}$. The sequencing reaction applied the ABI Dye Terminator technology and an Applied Biosystems 3130xl DNAsequencer (Applied Biosystems). As an exception to standard conditions, GM3F-CF1489R amplicons were sequenced with an elongation temperature of $62^{\circ} \mathrm{C}$, the optimal annealing temperature of CF1489R. The 16S rRNA gene sequences were analysed with Applied Biosystems Sequencing Analysis 5.2 (Applied Biosystems, Foster City, USA) and assembled with Sequencer 4.6 (Gene Codes, Ann Arbor, MI).

The initial phylogenetic affiliation was assigned using the Ribosomal Database Project [11]. After alignment of sequences in ARB, evolutionary distances were calculated by the method of Jukes and Cantor [25] and a phylogenetic consensus tree was constructed with neighbour-joining [42] using a $0 \%$ and $40 \%$ base frequency filter in ARB.

The 16S rRNA gene sequences were deposited in GenBank under Acc. Nos. JX854056-JX854433.

\section{Results and discussion}

A total of 375 strains affiliated to Flavobacteriaceae were isolated from all samples investigated: seawater of Helgoland, sediment of Harlesiel and Jansand, and seawater, sediment and its porewater, phytoplankton, seaweed and animal specimens of Sylt in the German Bight. The affiliation was based on the current nomenclature of Flavobacteriaceae (Table S2). A novel species was defined by a $16 \mathrm{~S}$ rRNA gene sequence identity of between $95.0 \%$ and $98.7 \%$ (Table S3), and a novel genus was defined as $<95.0 \% 16 \mathrm{~S}$ rRNA gene sequence identity with validly described Flavobacteriaceae (Table S4) [45,54]. The strains represented 7 novel genera, 42 novel species, and 37 validated species, including four species previously isolated from the North Sea: 'G. forsetii' [5], M. forsetii [4], M. ruestringensis [9] and C. fucicola [24]. Detailed information on the strains is presented in Fig. 1 and Tables S3 and S4.

Selection criteria for isolation were initially the yellow colony colour and a short rod-shaped to filamentous cell morphology (Fig. S2) [6,7]. These criteria yielded a bias towards strains of the genera Arenibacter, Cellulophaga and Maribacter. A colourindependent screen for the presence of Flavobacteria colonies was developed with the new Flavobacteria-Cytophagia-specific reverse primer CF1489R. This primer covered $86 \%$ of all Bacteroidetes sequences present in the SILVA ref108_NR99 database. The primer exclusively amplified, in combination with the Bacteriaforward primer GM3F at $62^{\circ} \mathrm{C}$, a nearly full-length 16S rRNA gene of Flavobacteria or Cytophagia. The Bacteria-specific primers GM3F and 907R revealed the presence of Actinobacteria, Firmicutes, Alphaproteobacteria and Gammaproteobacteria among the non-Flavobacteria-Cytophagia colonies. Thus, the new primer was used for aerobic marine samples, and it was highly specific for Flavobacteria, Sphingobacteria and Cytophagia. Among the nonintensive yellow colonies detected as Flavobacteria were strains of Zunongwangia, 30 of 42 novel species, and 6 of 7 novel candidate genera.

\section{Variations in media and cultivation conditions}

All strains were cultured as chemoheterotrophic bacteria on (I) ZoBell's 2216 marine agar or (II) a defined artificial seawater medium supplemented with ammonium, phosphate, trace elements, and for carbon and energy sources with $2 \mathrm{~g} \mathrm{~L}^{-1}$ of complex carbon sources (yeast extract, peptone, casamino acids), defined carbohydrates (glucose, galactose, ramnose, xylose, cellobiose, malate, or N-acetylglucosamine), or a mixture of both. HaHa medium was more suitable than marine agar 2216 , partly because colonies of Vibrio, Alteromonas and Pseudoalteromonas were very large on 2216 and covered small adjacent colonies, which rarely formed colonies on HaHa medium. This may have been due to the absence of vitamins in the HaHa medium.

For a spring sample with a temperature of $6.4^{\circ} \mathrm{C}$, isolation and cultivation were performed at $11^{\circ} \mathrm{C}$. This experiment yielded strains representing 11 of 42 novel Flavobacteriaceae species and 3 of 7 novel candidate genera in our study, but only one of 37 known species. Even if the environmental temperature during the year reached mesophilic temperatures $\left(20^{\circ} \mathrm{C}\right)$, the observed shift towards novel species observed in cultivations at low temperature, near the in situ temperature, highlighted temperature as an important variable in isolation experiments.

Inoculation on plates was performed with traditional spreading techniques. Alternatively, one microlitre was spotted on a plate with a 96-pin replicator [53]. Twofold dilution series yielded plates with high numbers of single colonies per inoculation spot. To determine the time for colony formation, a spring pelagic water sample from Helgoland with an in situ temperature of $6.4^{\circ} \mathrm{C}$ was diluted and 1152 spots of a $0.1 \mu \mathrm{L}$ original seawater sample were observed for growth at $11^{\circ} \mathrm{C}$ for 300 days (Table 1). The CFU increased during the incubation time, and was comparable to a growth curve. After a lag phase of 10 days, the number of colony forming units (CFU) exponentially increased to 153 CFU until day 23 and reached 208 CFU on day 110. Besides Actinobacteria (e.g. Rhodococcus, Nocardioides), Alphaproteobacteria (Erythrobacter, Sulfitobacter and Brevundimonas) and Gammaproteobacteria (e.g. Marinobacter, Pseudoalteromonas), 88 yellow-orange to brownish pigmented colonies were obtained and they included 43 Flavobacteriaceae, which corresponded to $273 \mathrm{CFU}$ per $\mathrm{mL}$ seawater. The first Flavobacteriaceae colonies were strains of Krokinobacter, Croceibacter, Maribacter and Salegentibacter. Also, strains affiliated to Gillisia, Stenothermobacter, Arenibacter and Marixanthomonas required less than 20 days to form visible colonies. In contrast, strains of Cellulophaga, Flavobacterium and Nonlabens required at least 20 days for colony formation (Fig. 2). Several strains of novel species required long incubation times of several weeks, whereas over $80 \%$ of viable cells needed only three weeks to grow to visible colonies. The incubation time seemed to be an important factor for the cultivation of novel species.

Flint [17] suggested kanamycin as an effective agent for enhancing the culturability of "Flavobacterium" species because of growth inhibition of other bacteria. Therefore, plates with $2 \mathrm{~g} \mathrm{~L}^{-1}$ casamino acids were supplemented with $50 \mu \mathrm{g} \mathrm{mL}^{-1}$ kanamycin and inoculated with phytoplankton or sediment samples. In comparison with control plates, the number of white colonies was reduced on average by $50 \%$, whereas the number of yellow colonies remained nearly constant (Fig. S3). The Flavobacteria-Cytophagia-specific PCR was positive for $90 \%$ of the yellow colonies. This experiment confirmed the observations of Flint [17] and the resistance of many Flavobacteria to the aminoglycoside antibiotic kanamycin. Strains obtained from kanamycin-containing media affiliated with Arenibacter (1 strain), Cellulophaga (7), Gramella (6), Kriegella (1), Lutibacter (15), Maribacter (1), Mesonia (1), Muricauda (2), Saligentibacter (1), Sediminicola (1), Tenacibaculum (2), Winogradskyella (1), and Zobellia (9). Thus, selective isolation of certain genera was not observed by the application of kanamycin.

\section{Biogeography and culturability}

The genera Cellulophaga, Maribacter, Gramella, Arenibacter, Lutibacter, Zunongwangia, Olleya, Zobellia, and Muricauda were isolated frequently, with more than ten strains per species. Zunongwangia profunda (15 strains) and Gramella echinicola (13 strains) were exclusively isolated from one sampling site, in this case, from the porewater $1.5 \mathrm{~m}$ below the surface of West Beach, Sylt. Strains 


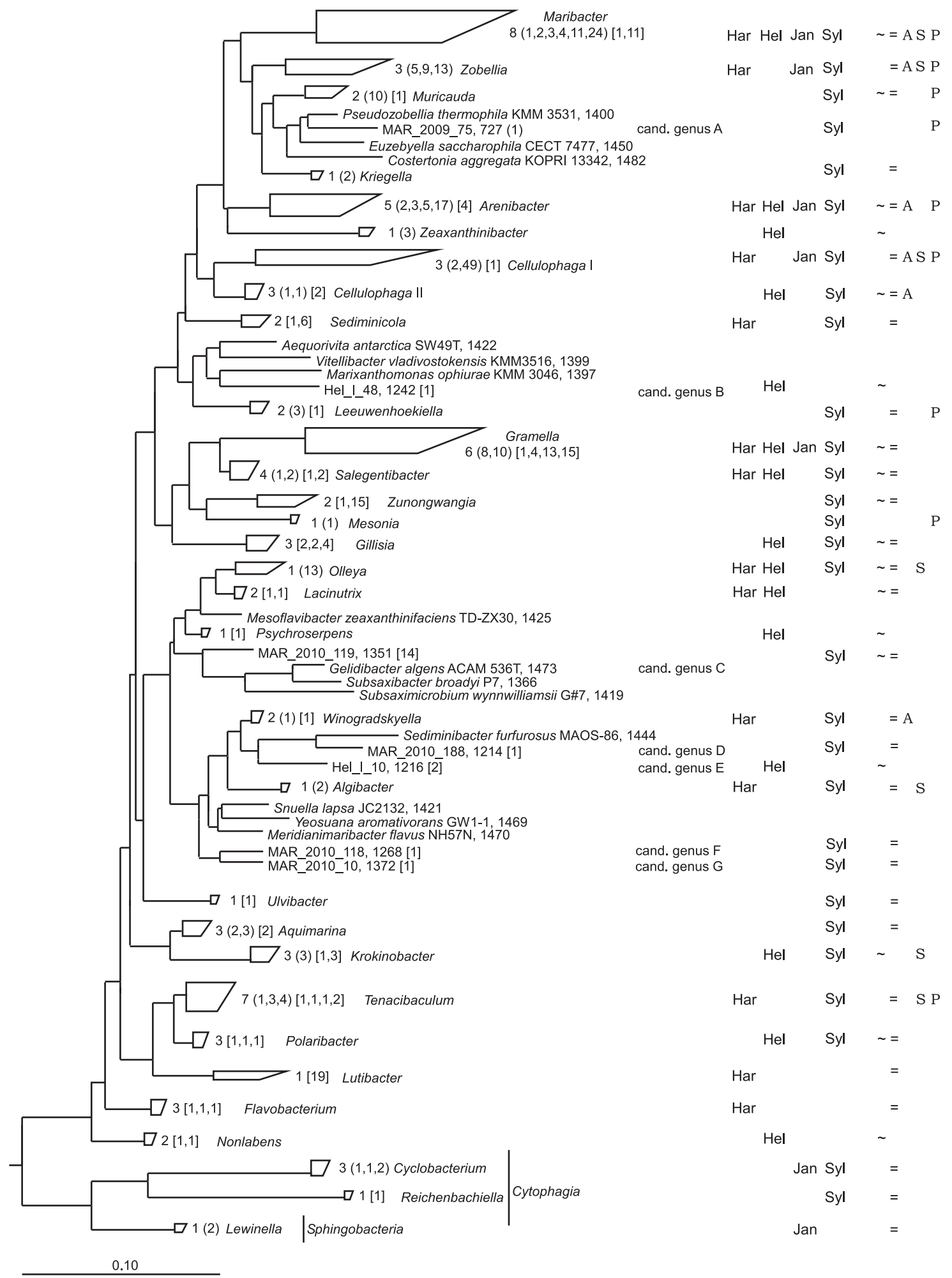

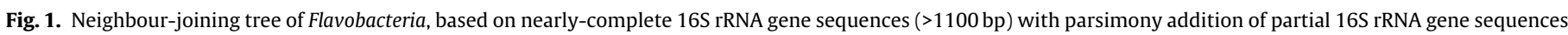

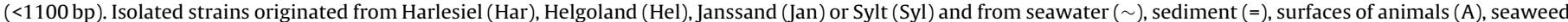

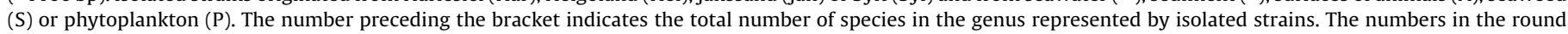

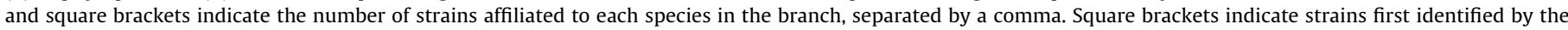
Flavobacteria-Cytophagia-specific PCR. The scale bar represents 10 nucleotide substitutions per 100 nucleotides.

affiliating with Lutibacter litoralis (19 strains) or Maribacter stanieri (11 strains) were only isolated from the sediment of Harlesiel or the seawater of Helgoland, respectively. All other strains affiliating with one species - as defined by the 16S rRNA gene sequence identity - were isolated from two or more sampling sites and types.
This reflected either the low resolution of the 98.7\% 16S rRNA gene sequence identity used as a boundary or the lack of a biogeography for many Flavobacteria in the German Bight.

In this study, the culturability of Flavobacteria from the North Sea on solid media was approximately one colony forming 
Table 1

Colony formation (CFU $1 \mathrm{~mL}^{-1}$ seawater) of a Helgoland spring seawater sample (April 4th, 2010) on HaHa medium incubated at $11^{\circ} \mathrm{C}$.

\begin{tabular}{|c|c|c|c|c|c|c|c|c|c|c|c|}
\hline Time (days) & 15 & 20 & 23 & 34 & 38 & 44 & 52 & 60 & 100 & 110 & 300 \\
\hline Total CFU & 227 & 533 & 1020 & 1100 & 1160 & 1213 & 1267 & 1320 & 1347 & 1387 & 1387 \\
\hline Pigmented CFU & 167 & 333 & 507 & 547 & 567 & 573 & 587 & 587 & 587 & 587 & 587 \\
\hline Flavobacteria CFU & 60 & 160 & 260 & 267 & 267 & 267 & 273 & 273 & 273 & 273 & 273 \\
\hline
\end{tabular}

unit per thousand flavobacterial cells, and strains of 26 known Flavobacteriaceae genera were cultivated. Previous studies had isolated strains of seven genera, Flavobacterium, Gillisia, Krokinobacter, Nonlabens, Polaribacter, Tenacibaculum and Winogradskyella [14,36,40,46,50,51], and corresponding 16S rRNA gene sequences were detected in cultivation-independent studies [3,41,44,49,58]. Furthermore, strains of the genera Algibacter, Aquimarina, Arenibacter, Cellulophaga, Gramella, Leeuwenhoekiella, Maribacter and Zobellia had been cultivated, but were not present in cultivationindependent studies [5,14,21,36,43,46,47,51]. The 16S rRNA gene sequences of Marixanthomonas and Psychroserpens were only found in cultivation-independent studies $[8,33]$. These observations showed that the diversity of culturable Flavobacteria from the North Sea has increased and, in contrast to previous reports $[14,46]$, a wide range of Flavobacteria was shown to grow well on solid agar media, although many important taxa still await cultivation.

\section{Physiological and chemotaxonomic observations}

The known types of gliding motility were observed: (I) spreading as a thin film or as waves (Cellulophaga, Tenacibaculum), (II) an outwards push even around the colony (Leeuwenhoekiella, Polaribacter, Zobellia) or (III) a flame-like pattern (Aquimarina, Krokinobacter, Pseudozobellia, Zobellia), and (IV) a rhizoid spreading along the streaking (Algibacter, Gramella, Maribacter, Zeaxanthinibacter). For Krokinobacter spp., movement by gliding was not determined, but putative gliding-related proteins were encoded in the genome of Krokinobacter sp. 4H-3-7-5 [30]. Strain SRO_11 that affiliated with Krokinobacter eikastus glided on marine agar 2216.

Iridescence [13] was briefly described among Flavobacteria [27], but intensively for Cellulophaga [26]. In this study, iridescence was observed in strains affiliated with the genera Cellulophaga, Algibacter and Maribacter. Flexirubin-type pigments [16] were detected in coherence with the species description in strains affiliating with Aquimarina, Kriegella, and Zobellia. Unexpectedly, strains MGE_SAT_544_1 and MAR_2010_101 among 31 strains of Arenibacter showed the bathochromic shift after $\mathrm{KOH}$ treatment. In contrast, the Ulvibacter strain MAR_2010_11 had no flexirubin-type pigment. Besides these exceptions, pigmentation, iridescence, gliding motility, agar lysis, and flexirubin as a chemical marker supported the taxonomy at the species level.

\section{Maribacter}

Fifty-seven strains were assigned to eight species within Maribacter, including M. stanieri, Maribacter dokdonensis, Maribacter sedimenticola, and $M$. forsetii [4] - a species previously isolated from Helgoland - and four novel species. Two strains of $M$. dokdonensis showed a glitter-like iridescence on the surface of the colony and gliding that followed the streaking in a rhizoid spreading pattern. None of the strains produced flexirubin-like pigments.

\section{Zobellia, candidate genus A, Muricauda and Kriegella}

A total of 28 strains were isolated that affiliated with three Zobellia species, Zobellia uliginosa, Zobellia amurskyensis and Zobellia russellii. All strains were positive for flexirubin-type pigments. Three strains of the species Z. russellii and one strain of Z. uliginosa lysed agar. Seven strains of all three species showed gliding motility in a flame-like pattern or even around the colony (Fig. 3). Ten strains affiliated with $M$. ruestringensis were flexirubin-type pigment negative and did not glide or lyse agar, except for strain MAR_2009_54. Both strains of Kriegella were flexirubin-type pigment positive, but showed no gliding. Strain MAR_2009_75 had a 16S rRNA gene sequence identity of $94.7 \%$ to the closest relative Pseudozobellia thermophile, thus representing the candidate genus A. Iridescence, agar lysis and flexirubin-type pigments were not observed. This strain was isolated from phytoplankton of Sylt and showed a flame-like gliding pattern on agar (Fig. 3).

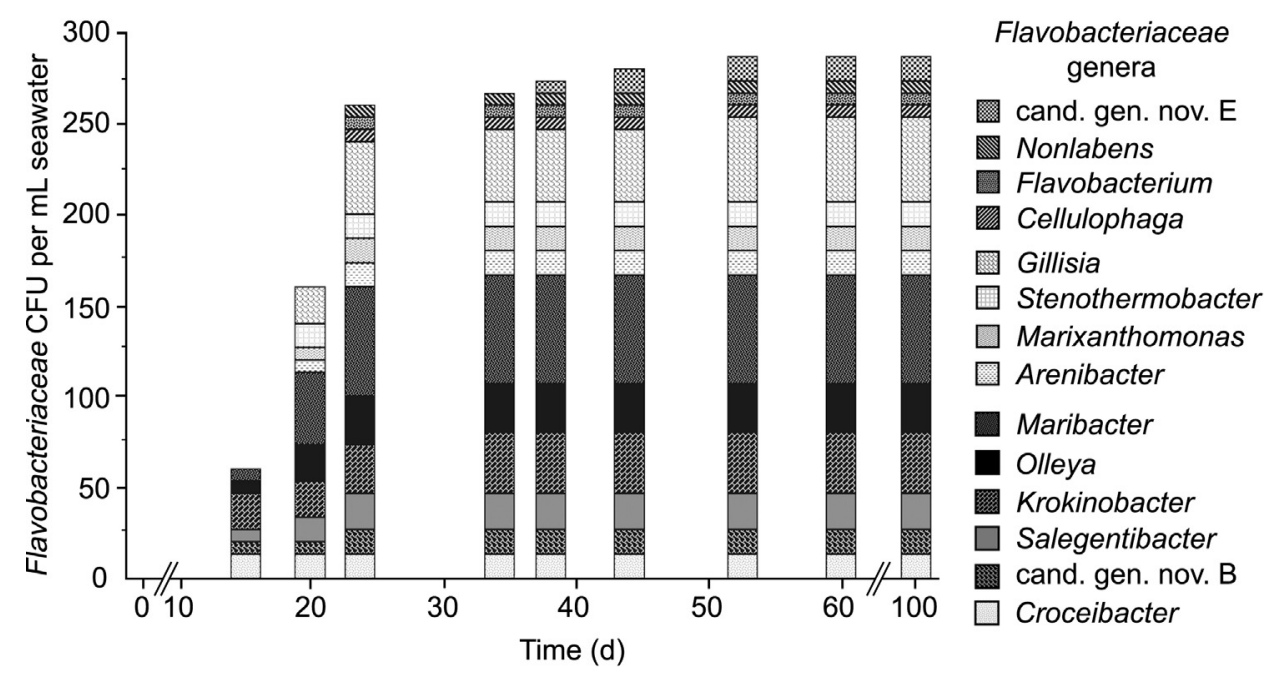

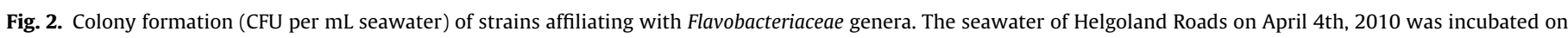
HaHa medium at $11^{\circ} \mathrm{C}$ for 300 days. 

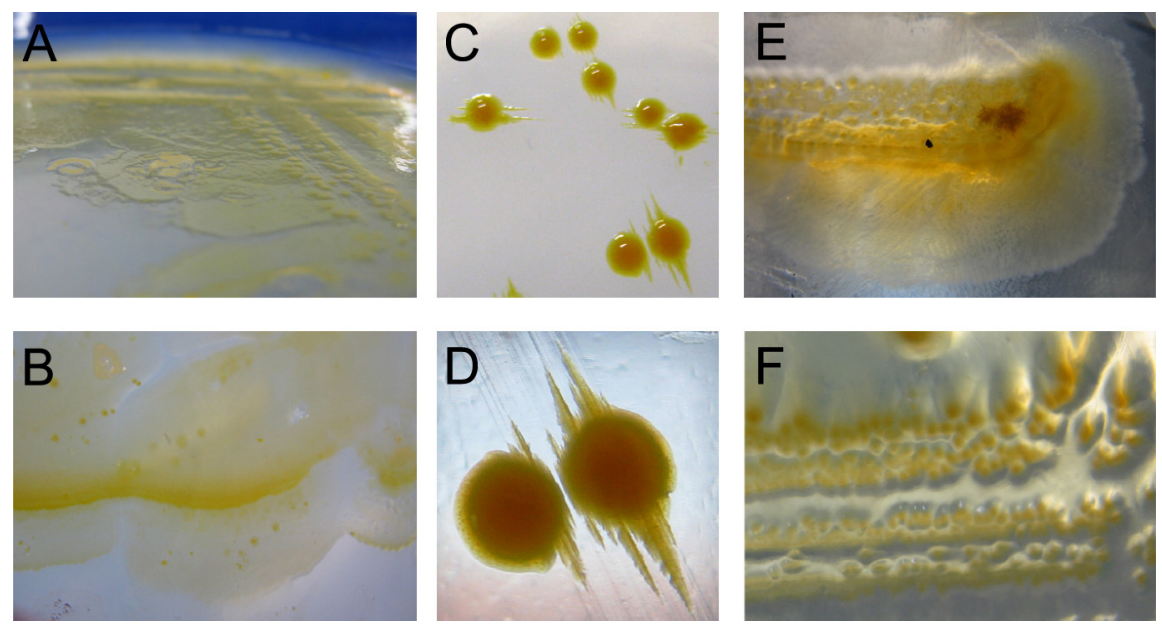

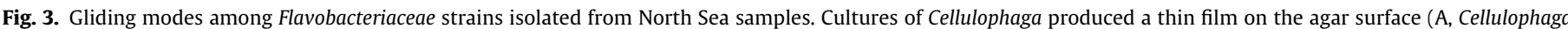

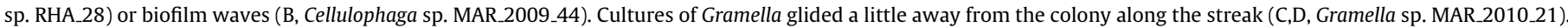

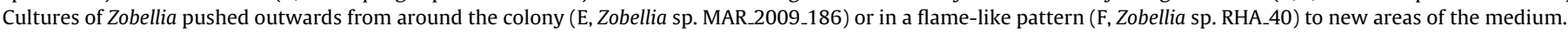

\section{Arenibacter and Zeaxanthinibacter}

A total of 31 strains were assigned to Arenibacter, including Arenibacter troitsensis, Arenibacter palladensis, Arenibacter echinorum and two novel Arenibacter spp.. Gliding, agar lysis and iridescence were not observed. Among the 31 strains, strains MAR_2010_101 and MGE_SAT_544_1 were flexirubin-type pigment positive. Three strains affiliating with Zeaxanthinibacter enoshimensis did not show iridescence, flexirubin-type pigments or agar lysis, but glided along the streaking (Fig. 3).

\section{Cellulophaga}

A total of 56 strains of Cellulophaga were isolated from sediment, seawater, biofilm, seaweed and animals of all sampling sites, and formed a monophyletic branch of two distinct subgroups in the $16 \mathrm{~S}$ rRNA gene tree, as described by Bernardet [6]. In the first subgroup, 52 strains were affiliated with Cellulophaga lytica or represented two novel Cellulophaga spp.. In the second subgroup, four strains were affiliated with Cellulophaga baltica, Cellulophaga pacifica or represented another novel Cellulophaga sp.. Gliding movement was observed for C. lytica and Cellulophaga sp. nov. I strains, with a faster spreading on the agar plate than colony formation, resulting in a thin film on the surface of the plate (Fig. 3). These cultures were isolated by serial dilution in artificial seawater followed by homogenous distribution on an agar plate. Twelve strains of $C$. lytica and strain RHA_19 showed a glitter-like iridescence.

Sediminicola, candidate genus B, and Leeuwenhoekiella

A total of seven strains isolated from sediment were assigned to Sediminicola luteus and a novel Sediminicola sp.. No flexirubintype pigments, gliding, agar lysis or iridescence were observed. Four strains of two novel species of Leeuwenhoekiella showed no flexirubin-type pigments, gliding, agar lysis or iridescence, but strain SRO_3 exhibited gliding motility. One strain isolated from the seawater of Helgoland only had a 90.4\% 16S rRNA gene sequence identity, and its closest relative was Marixanthomonas ophiurae which represented candidate genus B. Agar lysis, flexirubin-type pigments or iridescence were not observed, but gliding cells were observed around colonies.

\section{Gramella}

A total of 32 strains were isolated from sediment that affiliated with G. echinicola, Gramella gaetbulicola, Gramella marina and a novel species of Gramella. Nineteen strains isolated from seawater and sediment affiliated with Gramella portivictoriae and ' $G$. forsetii' [5]. Gliding was observed for three strains which moved from the colony along the streak (Fig. 3). Iridescence, agar lysis and flexirubin-type pigments were not observed.

\section{Salegentibacter, Zunongwangia, Mesonia, and Gillisia}

A total of seven strains were assigned to Salegentibacter mishustinae, Salegentibacter salarius, and two novel Salegentibacter spp.. Sixteen strains with a cell size of less than $1.5 \mu \mathrm{m}$ and a faint yellow colony colour were assigned to $Z$. profunda and one novel Zunongwangia sp.. Mesonia algae was represented by one strain. In Gillisia, eight strains were affiliated to Gillisia mitskevichiae, Gillisia myxillae, or depicted a novel species of Gillisia. The strains of Salegentibacter, Zunongwangia, Mesonia, and Gillisia were negative for flexirubin-type pigments, iridescence, agar lysis and gliding.

\section{Olleya, Lacinutrix, Psychroserpens and candidate genus $C$}

Thirteen strains represented a novel species of Olleya, two strains were assigned to Lacinutrix copepodicola and Lacinutrix sp. nov., and one strain to a novel Psychroserpens sp.. Thirteen strains isolated from the porewater $1.5 \mathrm{~m}$ below the sand surface at the driftline of Sylt West Beach represented the candidate genus C, with a 16S rRNA gene sequence identity of $94.0 \%$ with Gelidibacter algens. The strains of Olleya, Lacinutrix, Psychroserpens, and the candidate genus $\mathrm{C}$ were negative for flexirubin-type pigments, iridescence, agar lysis and gliding.

\section{Winogradskyella, Algibacter and candidate genera $D, E, F$, and $G$}

A total of four strains represented two novel Winogradskyella spp. and two novel Algibacter spp.. Three strains were assigned to the candidate genera $\mathrm{D}$ and $\mathrm{E}$, with a $16 \mathrm{~S}$ rRNA gene sequence identity of $94.0 \%$ and $91.4 \%$ to the next relative Sediminibacter furfurosus, respectively. Two strains represented the candidate genera F and G, with the next relative being Meridianimaribacter flavus with a 16S rRNA gene sequence identity of $94.7 \%$ and $95.0 \%$, respectively. Gliding, agar lysis, iridescence and flexirubin-type pigments were not observed for strains of Winogradskyella and the candidate genera D, E, F, and G. For Algibacter strains, iridescence and gliding along the streaking (Fig. 3) were observed. 
Ulvibacter, Aquimarina and Krokinobacter

One strain represented a novel species of Ulvibacter but it did not produce flexirubin-type pigments, in contrast to the current description of the genus Ulvibacter. Seven strains with cells of $>10 \mu \mathrm{m}$ in length grouped into three species of Aquimarina, Aquimarina macrocephali and two novel Aquimarina spp.. The flexirubin test was positive for strains of two novel species of Aquimarina, but not for strains of $A$. macrocephali. Gliding motility was observed for strains of $A$. macrocephali and Aquimarina sp. nov. I, isolated from sediment, but not for strains of Aquimarina sp. nov. II, isolated from seawater. Seven strains affiliated with Krokinobacter, including K. eikastus and two novel Krokinobacter spp.. Strain SRO_199 performed flame-like gliding and agar lysis was observed for strain SRO_18.

\section{Tenacibaculum, Polaribacter and Lutibacter}

A total of 13 strains were isolated from seawater, sediment, phytoplankton and algae affiliating with Tenacibaculum gallaicum and Tenacibaculum litoreum, or they represented five novel species of Tenacibaculum. Strains of T. gallaicum and Tenacibaculum sp. nov. II performed gliding with faster gliding than colony formation, resulting in a thin film on the agar plate (Fig. 3). Three novel species of Polaribacter were isolated and strain Hel1_85 performed gliding, even around the colony. Nineteen strains from the sediment of Harlesiel affiliated with $L$. litoralis. In contrast to the cell size of less than $1.5 \mu \mathrm{m}$ for Polaribacter and Lutibacter strains, the Tenacibaculum strains formed filaments of more than $100 \mu \mathrm{m}$ in length.

\section{Flavobacterium and Nonlabens}

Three strains were isolated from sediment that affiliated with three species of Flavobacterium, Flavobacterium gelidilacus, and two Flavobacterium sp. nov.. Two strains isolated from seawater of Helgoland represented novel species of the genus Nonlabens. Gliding, iridescence, agar lysis and flexirubin-type pigments were not observed.

\section{Cytophagia and Sphingobacteria}

An orange to brown colony colour and rod-shaped cells characterized non-motile strains affiliating to Reichenbachiella (family Flammeovirgaceae), Lewinella (family Saprospiraceae) and Cyclobacterium (family Cyclobacteriaceae).

\section{Conclusion and future perspectives}

In this study, cultivation of marine Flavobacteriaceae was demonstrated on agar plates from diverse habitats. A broad phylogenetic diversity was obtained by different cultivation approaches for pelagic and benthic Flavobacteria, a Flavobacteria-Cytophagia specific PCR, and a suitable medium. This collection of Flavobacteriaceae from the German Bight of the North Sea provided model organisms of marine aerobic heterotrophic bacteria and will give access to a variety of carbohydrate active enzymes [10,49].

\section{Acknowledgments}

We would like to thank the M.Sc. Marine Microbiology (MarMic) classes of 2012, 2013 and 2014, Greta Reintjes, Maria Gerdes, Sven Le Moine Bauer, Thomas Blume and Sathish Mayanna for their assistance in cultivation. We also thank Dr. Justus van Beusekom, Dr. Gunnar Gerdts and the Alfred-Wegener-Institute für Polar- und Meeresforschung for hosting us in the guest laboratories at the
Wadden Sea Station Sylt and the Biological Institute Helgoland. This research was funded by the Max Planck Society.

\section{Appendix A. Supplementary data}

Supplementary material related to this article can be found, in the online version, at http://dx.doi.org/10.1016/j.syapm. 2013.06.006.

\section{References}

[1] Abell, G.C.J., Bowman, J.P. (2005) Colonization and community dynamics of class Flavobacteria on diatom detritus in experimental mesocosms based on Southern Ocean seawater. FEMS Microbiol. Ecol. 53, 379-391.

[2] Alongi, D.M. 1998 Coastal Ecosystem Processes, CRC Press, Boca Raton, USA.

[3] Alonso, C., Warnecke, F., Amann, R., Pernthaler, J. (2007) High local and global diversity of Flavobacteria in marine plankton. Environ. Microbiol. 9, 1253-1266.

[4] Barbeyron, T., Carpentier, F., L'Haridon, S., Schüler, M., Michel, G., Amann, R. (2008) Description of Maribacter forsetii sp. nov., a marine Flavobacteriaceae isolated from North Sea water, and emended description of the genus Maribacter. Int. J. Syst. Evol. Microbiol. 58, 790-797.

[5] Bauer, M., Kube, M., Teeling, H., Richter, M., Lombardot, T., Allers, E., Würdemann, C.A., Quast, C., Kuhl, H., Knaust, F., Woebken, D., Bischof, K., Mussmann, M., Choudhuri, J.V., Meyer, F., Reinhardt, R., Amann, R.I., Glöckner, F.O. (2006) Whole genome analysis of the marine Bacteroidetes 'Gramella forsetii' reveals adaptations to degradation of polymeric organic matter. Environ. Microbiol. 8 , 2201-2213.

[6] Bernardet, J.-F. (2010) Class II. Flavobacteriia class. nov. In: Krieg, N.R., Staley, J.T., Brown, D.R., Hedlund, B.P., Paster, B.J., et al. (Eds.), Bergey's Manual of Systematic Bacteriology. The Bacteroidetes, Spirochaetes, Tenericutes (Mollicutes), Acidobacteria, Fibrobacteres, Fusobacteria, Dictyoglomi, Gemmatimonadetes, Lentisphaerae, Verrucomicrobia, Chlamydiae, and Planctomycetes, Springer, New York, NY, pp. 106-314.

[7] Bernardet, J.F., Nakagawa, Y., Holmes, B. (2002) Proposed minimal standards for describing new taxa of the family Flavobacteriaceae and emended description of the family. Int. J. Syst. Evol. Microbiol. 52, 1049-1070.

[8] Brandt, P., Gerdts, G., Boersma, M., Wiltshire, K.H., Wichels, A. (2010) Comparison of different DNA-extraction techniques to investigate the bacterial community of marine copepods. Helgoland Mar. Res. 64, 331-342.

[9] Bruns, A., Rohde, M., Berthe-Corti, L. (2001) Muricauda ruestringensis gen. nov. sp. nov., a facultatively anaerobic, appendaged bacterium from German North Sea intertidal sediment. Int. J. Syst. Evol. Microbiol. 51, 1997-2006.

[10] Cantarel, B.L., Coutinho, P.M., Rancurel, C., Bernard, T., Lombard, V., Henrissat, B. (2009) The Carbohydrate-Active EnZymes database (CAZy): an expert resource for glycogenomics. Nucleic Acids Res. 37, D233-D238.

[11] Cole, J.R., Wang, Q., Cardenas, E., Fish, J., Chai, B., Farris, R.J., Kulam-SyedMohideen, A.S., McGarrell, D.M., Marsh, T., Garrity, G.M., Tiedje, J.M. (2009) The Ribosomal Database Project: improved alignments and new tools for rRNA analysis. Nucleic Acids Res. 37, D141-D145.

[12] Colwell, R.R., Citarella, R.V., Chen, P.K. (1966) DNA base composition of Cytophaga marinoflava n. sp. determined by buoyant density measurements in cesium chloride. Can. J. Microbiol. 12, 1099-1103.

[13] Doucet, S.M., Meadows, M.G. (2009) Iridescence: a functional perspective. J. R. Soc. Interface 6, S115-S132.

[14] Eilers, H., Pernthaler, J., Glöckner, F.O., Amann, R. (2000) Culturability and in situ abundance of pelagic bacteria from the North Sea. Appl. Environ. Microbiol. 66, 3044-3051.

[15] Euzéby, J.P. (1997) List of bacterial names with standing in nomenclature: a folder available on the Internet. Int. J. Syst. Bacteriol. 47, 590-592, http://www.bacterio.cict.fr/

[16] Fautz, E., Reichenbach, H. (1980) A simple test for flexirubin-type pigments. FEMS Microbiol. Lett. 8, 87-91.

[17] Flint, K.P. (1985) A note on a selective agar medium for the enumeration of Flavobacterium species in water. J. Appl. Bacteriol. 59, 561-566.

[18] Frette, L., Jørgensen, N.O.G., Irming, H., Kroer, N. (2004) Tenacibaculum skagerrakense sp. nov., a marine bacterium isolated from the pelagic zone in Skagerrak, Denmark. Int. J. Syst. Evol. Microbiol. 54, 519-524

[19] Gao, H., Matyka, M., Liu, B., Khalili, A., Kostka, J.E., Collins, G., Jansen, S., Holtappels, M., Jensen, M.M., Badewien, T.H., Beck, M., Grunwald, M., de Beer, D., Lavik, G., Kuypers, M.M.M. (2012) Intensive and extensive nitrogen loss from intertidal permeable sediments of the Wadden Sea. Limnol. Oceanogr. 57, 185-198.

[20] Gómez-Pereira, P.R., Fuchs, B.M., Alonso, C., Oliver, M.J., van Beusekom, J.E.E. Amann, R. (2010) Distinct flavobacterial communities in contrasting water masses of the North Atlantic Ocean. ISME J. 4, 472-487.

[21] Grossart, H.P., Schlingloff, A., Bernhard, M., Simon, M., Brinkhoff, T. (2004) Antagonistic activity of bacteria isolated from organic aggregates of the German Wadden Sea. FEMS Microbiol. Ecol. 47, 387-396.

[22] Hansen, G.H., Bergh, Ø., Michaelsen, J., Knappskog, D. (1992) Flexibacter ovolyticus sp. nov., a pathogen of eggs and larvae of Atlantic halibut, Hippoglossus hippoglossus L. Int. J. Syst. Bacteriol. 42, 451-458.

[23] Janssen, P.H., Yates, P.S., Grinton, B.E., Taylor, P.M., Sait, M. (2002) Improved culturability of soil bacteria and isolation in pure culture of novel members of 
the divisions Acidobacteria, Actinobacteria, Proteobacteria, and Verrucomicrobia. Appl. Environ. Microbiol. 68, 2391-2396.

[24] Johansen, J.E., Nielsen, P., Sjohølm, C. (1999) Description of Cellulophaga baltica gen. nov., sp. nov., and Cellulophaga fucicola gen. nov., sp. nov. and reclassification of [Cytophaga] lytica to Cellulophaga lytica gen. nov., comb. nov. Int. J. Syst. Bacteriol. 49, 1231-1240.

[25] Jukes, T.H., Cantor, C.R. (1969) Evolution of protein molecules. In: Munro, H.N. (Ed.), Mammalian Protein Metabolism, Academic Press, New York, USA, pp, $21-132$.

[26] Kientz, B., Marie, P., Rosenfeld, E. (2012) Effect of abiotic factors on the unique glitter-like iridescence of Cellulophaga lytica. FEMS Microbiol. Lett. 333, $101-108$.

[27] Kientz, B., Vukusic, P., Luke, S., Rosenfeld, E. (2012) Iridescence of a marine bacterium and classification of prokaryotic structural colors. Appl. Environ. Microbiol. 78, 2092-2099.

[28] Kirchman, D.L. (2002) The ecology of Cytophaga-Flavobacteria in aquatic environments. FEMS Microbiol. Ecol. 39, 91-100.

[29] Klindworth, A., Pruesse, E., Schweer, T., Peplies, J., Quast, C., Horn, M., Glöckner, F.O. (2013) Evaluation of general 16S ribosomal RNA gene PCR primers for classical and next-generation sequencing-based diversity studies. Nucleic Acids Res. 41, e1.

[30] Klippel, B., Lochner, A., Bruce, D.C., Davenport, K.W., Detter, C., Goodwin, L.A., Han, J., Han, S.S., Hauser, L., Land, M.L., Nolan, M., Ovchinnikova, G., Pennacchio, L., Pitluck, S., Tapia, R., Woyke, T., Wiebusch, S., Basner, A., Abe, F., Horikoshi, K., Keller, M., Antranikian, G. (2011) Complete genome sequences of Krokinobacter sp. strain 4H-3-7-5 and Lacinutrix sp. strain 5H3-7-4, polysaccharide-degrading members of the family Flavobacteriaceae. J. Bacteriol. 193, 4545-4546.

[31] Llobet-Brossa, E., Rosselló-Móra, R., Amann, R. (1998) Microbial community composition of Wadden Sea sediments as revealed by fluorescence in situ hybridization. Appl. Environ. Microbiol. 64, 2691-2696.

[32] Ludwig, W., Strunk, O., Westram, R., Richter, L., Meier, H., Yadhukumar, Buchner, A., Lai, T., Steppi, S., Jobb, G., Förster, W., Brettske, I., Gerber, S., Ginhart, A.W., Gross, O., Grumann, S., Hermann, S., Jost, R., König, A., Liss, T., Lüßmann, R., May, M., Nonhoff, B., Reichel, B., Strehlow, R., Stamatakis, A., Stuckmann, N., Vilbig, A., Lenke, M., Ludwig, T., Bode, A., Schleifer, K.H. (2004) ARB: a software environment for sequence data. Nucleic Acids Res. 32, 1363-1371.

[33] Musat, N., Werner, U., Knittel, K., Kolb, S., Dodenhof, T., van Beusekom, J.E.E., de Beer, D., Dubilier, N., Amann, R. (2006) Microbial community structure of sandy intertidal sediments in the North Sea, Sylt-Rømø Basin, Wadden Sea. Syst. Appl. Microbiol. 29, 333-348.

[34] Muyzer, G., Teske, A., Wirsen, C., Jannasch, H. (1995) Phylogenetic relationships of Thiomicrospira species and their identification in deep-sea hydrothermal vent samples by denaturing gradient gel electrophoresis of 16S rDNA fragments. Arch. Microbiol. 164, 165-172.

[35] Nedashkovskaya, O.I., Vancanneyt, M., Dawyndt, P., Engelbeen, K., Vandemeulebroecke, K., Cleenwerck, I., Hoste, B., Mergaert, J., Tan, T.-L., Frolova, G.M., Mikhailov, V.V., Swings, J. (2005) Reclassification of [Cytophaga] marinoflava Reichenbach 1989 as Leeuwenhoekiella marinoflava gen. nov., comb. nov. and description of Leeuwenhoekiella aequorea sp. nov. Int. J. Syst. Evol. Microbiol. 55, 1033-1038.

[36] O’Sullivan, L.A., Rinna, J., Humphreys, G., Weightman, A.J., Fry, J.C. (2006) Culturable phylogenetic diversity of the phylum 'Bacteroidetes' from river epilithon and coastal water and description of novel members of the family Flavobacteriaceae: Epilithonimonas tenax gen. nov., sp. nov. and Persicivirga xylanidelens gen. nov., sp. nov. Int. J. Syst. Evol. Microbiol. 56, 169-180.

[37] Pfennig, N., Trüper, H.G. (1981) Isolation of members of the families Chromatiaceae and Chlorobiaceae. In: Starr, M.P., Stolp, H., Trüper, H.G., Balows, A., Schlegel, H.G. (Eds.), The Prokaryotes, Springer-Verlag, Berlin, Germany, pp. 279-289.

[38] Port, A., Gurgel, K.-W., Staneva, J., Schulz-Stellenfleth, J., Stanev, E.V. (2011) Tidal and wind-driven surface currents in the German Bight: HFR observations versus model simulations. Ocean Dyn. 61, 1567-1585.

[39] Pruesse, E., Quast, C., Knittel, K., Fuchs, B.M., Ludwig, W.G., Peplies, J., Glöckner, F.O. (2007) SILVA: a comprehensive online resource for quality checked and aligned ribosomal RNA sequence data compatible with ARB. Nucleic Acids Res. 35, 7188-7196.
[40] Riedel, T., Tomasch, J., Buchholz, I., Jacobs, J., Kollenberg, M., Gerdts, G., Wichels A., Brinkhoff, T., Cypionka, H., Wagner-Döbler, I. (2010) Constitutive expression of the proteorhodopsin gene by a flavobacterium strain representative of the proteorhodopsin-producing microbial community in the North Sea. Appl. Environ. Microbiol. 76, 3187-3197.

[41] Rink, B., Martens, T., Fischer, D., Lemke, A., Grossart, H.P., Simon, M., Brinkhoff T. (2008) Short-term dynamics of bacterial communities in a tidally affected coastal ecosystem. FEMS Microbiol. Ecol. 66, 306-319.

[42] Saitou, N., Nei, M. (1987) The neighbor-joining method: a new method for reconstructing phylogenetic trees. Mol. Biol. Evol. 4, 406-425.

[43] Salaün, S., Kervarec, N., Potin, P., Haras, D., Piotto, M., La Barre, S. (2010) Whole-cell spectroscopy is a convenient tool to assist molecular identification of cultivatable marine bacteria and to investigate their adaptive metabolism. Talanta 80,1758-1770.

[44] Sapp, M., Wichels, A., Gerdts, G. (2007) Impacts of cultivation of marine diatoms on the associated bacterial community. Appl. Environ. Microbiol. 73, 3117-3120.

[45] Stackebrandt, E., Ebers, J. (2006) Taxonomic parameters revisited: tarnished gold standards. Microbiol. Today 33, 152-155.

[46] Stevens, H., Simon, M., Brinkhoff, T. (2009) Cultivable bacteria from bulk water aggregates, and surface sediments of a tidal flat ecosystem. Ocean Dyn. 59, 291-304.

[47] Stevens, H., Stübner, M., Simon, M., Brinkhoff, T. (2005) Phylogeny of Proteobacteria and Bacteroidetes from oxic habitats of a tidal flat ecosystem. FEMS Microbiol. Ecol. 54, 351-365.

[48] Suzuki, M., Nakagawa, Y., Harayama, S., Yamamoto, S. (2001) Phylogenetic analysis and taxonomic study of marine Cytophaga-like bacteria: proposal for Tenacibaculum gen. nov. with Tenacibaculum maritimum comb. nov. and Tenacibaculum ovolyticum comb. nov., and description of Tenacibaculum mesophilum sp. nov. and Tenacibaculum amylolyticum sp. nov. Int. J. Syst. Evol. Microbiol. 51, 1639-1652.

[49] Teeling $H$., Fuchs, B.M., Becher, D., Klockow, C., Gardebrecht, A., Bennke, C.M., Kassabgy, M., Huang, S., Mann, A.J., Waldmann, J., Weber, M., Klindworth, A., Otto, A., Lange, J., Bernhardt, J., Reinsch, C., Hecker, M., Peplies, J., Bockelmann, F.D., Callies, U., Gerdts, G., Wichels, A., Wiltshire, K.H., Glöckner, F.O., Schweder, T., Amann, R. (2012) Substrate-controlled succession of marine bacterioplankton populations induced by a phytoplankton bloom. Science 336, 608-611.

[50] Teske, A., Brinkhoff, T., Muyzer, G., Moser, D.P., Rethmeier, J. Jannasch, H.W. (2000) Diversity of thiosulfate-oxidizing bacteria from marine sediments and hydrothermal vents. Appl. Environ. Microbiol. 66, 3125-3133.

[51] Wichels, A., Würtz, S., Döpke, H., Schütt, C., Gerdts, G. (2006) Bacterial diversity in the breadcrumb sponge Halichondria panicea (Pallas). FEMS Microbiol. Ecol. 56, 102-118.

[52] Widdel, F., Bak, F. (1992) Gram-negative mesophilic sulfate-reducing bacteria. In: Balows, A., Trüper, H.G., Dworkin, M., Harder, W. (Eds.), The Prokaryotes, Springer Verlag, Berlin, Germany, pp. 3352-3378.

[53] Winkelmann, N., Harder, J. (2009) An improved isolation method for attached living Planctomycetes of the genus Rhodopirellula. J. Microbiol. Methods 77, 276-284.

[54] Yarza, P., Ludwig, W., Euzéby, J., Amann, R., Schleifer, K.-H., Glöckner F.O., Rosselló-Móra, R. (2010) Update of the All-Species Living Tree Project based on 16S and 23S rRNA sequence analyses. Syst. Appl. Microbiol. 33, 291-299.

[55] Zinger, L., Amaral-Zettler, L.A., Fuhrman, J.A., Horner-Devine, M.C., Huse, S.M., Welch, D.B.M., Martiny, J.B.H., Sogin, M., Boetius, A., Ramette, A. (2011) Global patterns of bacterial beta-diversity in seafloor and seawater ecosystems. PLoS ONE 6, e24570.

[56] ZoBell, C.E. (1941) Studies on marine bacteria. I. The cultural requirements of heterotrophic aerobes. J. Mar. Res. 4, 42-75.

[57] ZoBell, C.E., Johnson, F.H. (1949) The influence of hydrostatic pressure on the growth and viability of terrestrial and marine bacteria. J. Bacteriol. 57, 179-189.

[58] Zubkov, M.V., Fuchs, B.M., Archer, S.D., Kiene, R.P., Amann, R., Burkill, P.H. (2001) Linking the composition of bacterioplankton to rapid turnover of dissolved dimethylsulphoniopropionate in an algal bloom in the North Sea. Environ. Microbiol. 3, 304-311. 